\title{
BIOSYNTHESIS OF INDUSTRIAL ENZYMES BY FREE AND IMMOBILIZED Alicyclobacillus spp IN DIFFERENT MATRICES AND THE USE OF ULTRAFILTRATION IN THE ENZYMES CONCENTRATION
}

\author{
Suelen Pereira Ruiz ${ }^{\mathrm{a}}$, Juliana Harumi Miyoshia , Gabriela Gregolin Gimenez ${ }^{\mathrm{a}}$, Camila Ortiz Martinez ${ }^{\mathrm{a}}$, Benício Alves de \\ Abreu Filho ${ }^{\mathrm{b}}$ and Graciette Matiolia,* \\ aDepartamento de Farmácia, Universidade Estadual de Maringá, Av. Colombo, 5790, 87020-900 Maringá - PR, Brasil \\ bDepartamento de Ciências Básicas da Saúde, Universidade Estadual de Maringá, Av. Colombo, 5790, 87020-900 Maringá - PR, \\ Brasil
}

Recebido em 26/05/2017; aceito em 13/07/2017; publicado na web em 22/08/2017

\begin{abstract}
The biosynthesis of amylase and collagenase, produced by A. acidocaldarius and A. sendaiensis respectively, were studied, and different matrices evaluated for the microorganisms immobilization and enzymes production optimization, such as loofa sponge, alginate-sponge and alginate, followed by concentration through ultrafiltration. Using a wheat bran substrate, the amylase enzyme displayed enzymatic activity of $0.45 \mathrm{U} \mathrm{mL}^{-1}$ and optimum temperature and $\mathrm{pH}$ conditions of $75^{\circ} \mathrm{C}$ and $\mathrm{pH} 3.0$, respectively. Thermal stability was in the range of 55 to $60{ }^{\circ} \mathrm{C}$. The apparent $\mathrm{Km}_{\text {and }} \mathrm{Vmax}$ were $3.2 \mathrm{mg} \mathrm{mL}^{-1}$ and $0.5 \mathrm{U} \mathrm{mL}^{-1}$, respectively. The production of collagenase by $A$. sendaiensis was carried out with potato dextrose broth substrate and the activity obtained was $7.2 \mathrm{U} \mathrm{mL}^{-1}$. For amylase, the best results were obtained from immobilization in loofa sponge and the use of ultrafiltration $\left(0.67 \mathrm{U} \mathrm{mL}^{-1}\right)$ and for the collagenase extract, from the free biomass and ultrafiltration $\left(13.6 \mathrm{U} \mathrm{mL}^{-1}\right)$. The use of an ultrafiltration system enabled an average increase of 54\% in the activity of both enzymes. Therefore, Alicyclobacillus are capable of producing enzymes of industrial interest, with the possibility of economically viable application of the substrate, and the use of immobilization and ultrafiltration produced positive results.
\end{abstract}

Keywords: Alicyclobacillus; amylase; cell immobilization; collagenase; ultrafiltration.

\section{INTRODUCTION}

The Alicyclobacillus genus comprises thermoacidophilic and heterotrophic bacteria. These are aerobic, spore forming organisms, with optimum growth temperatures from 45 to $70{ }^{\circ} \mathrm{C}$, and optimum $\mathrm{pH}$ of between 2.0 and 7.0. They are highly thermally resistance to pasteurization processes, and are considered contaminants of thermoprocessed food products. ${ }^{1}$ Enzymes produced by such microorganisms have been studied for use in various industrial applications, including galactosidase, esterases, proteases and amylases, due to their thermostable characteristics. ${ }^{2-5}$ The Alicyclobacillus acidocaldarius and Alicyclobacillus sendaiensis species have been evaluated for the production of both amylase and collagenase, respectively.

The 1,4- $\alpha$-glucan hydrolase amylases (EC 3.2.1.1) hydrolyze the $\alpha-1,4$ glycosidic bonds and represent about a quarter of the market for industrial enzymes. Most starch industry processes involve starch hydrolysis by these amylases into glucose, maltose or oligosaccharide syrups that can be used in fermentations to produce a number of chemicals such as ethanol, lysine or citric acid. ${ }^{6}$

In industrial processing, starch is gelatinized by heating, followed by two enzymatic steps, known commercially as liquefaction (by $\alpha$-amylase) and saccharification (by glucoamylase). Most commercial $\alpha$-amylases operate at high temperatures, such as 90 to $95^{\circ} \mathrm{C}$ and with $\mathrm{pH}$ levels between 6.0 to 6.5 , differing from glucoamylases, which have an optimum $\mathrm{pH}$ of 4.0 to 4.5 and temperature from 60 to $65^{\circ} \mathrm{C}$. 7 This process is costly and generates a high energy consumption, as well as repeated temperature and $\mathrm{pH}$ adjustments for enzymatic activity.

Various conventional carbon sources such as starch, maltose, and glucose have been used for the production of the amylase enzyme by microorganisms. These constituents are costly for the industry

*e-mail: gmatioli@uem.br and, therefore their substitution by economically feasible means, such as agricultural and agroindustrial by-products, is desirable. ${ }^{8}$ In this context, the use of bran as a carbon source for industrial use is of considerable interest.

Another enzyme of industrial interest is collagenolytic protease, obtainable from Alicyclobacillus sendaiensis. Collagen is an insoluble protein that represents approximately $30 \%$ of the total weight of animal proteins and is produced in large quantities as a cattle and pig industry byproduct. The enzymatic degradation of collagen and gelatin allows the widespread use of these structural proteins, as collagen peptides have biological activities of interest to the food, cosmetics and pharmaceutical sectors. ${ }^{9}$

Cell immobilization techniques for the extracellular enzymes production have advantages over the conventional fermentation process when the use of free cells is compared. These include repeated and prolonged use of cells, reduced contamination risk, continuous fermentation in less sophisticated reactors, and the ease of separating cells from the fermentation medium. ${ }^{10}$

Various cell immobilization techniques have been used for the biotechnological processes optimization, such as gel entrapment, adsorption and covalent attachment. The immobilization method and the mechanical properties of the matrix are significant factors that affect the operational stability of the biocatalysts. ${ }^{11}$ An ideal matrix for immobilization should be strong, resistant to operating conditions and preferably have an open structure. ${ }^{12}$ Among these techniques, the use of loofa sponge as a support for immobilization has been studied, and as a low cost, porous, non-toxic and biodegradable matrix, presenting many benefits. ${ }^{13}$

The ultrafiltration system is one of the techniques used in the proteins concentration. It has been applied in various biotechnological processes, and due to the efficient molecules separation such as proteins and enzymes, it can be used as a primary purification step with low cost and energetic consumption..$^{14,15}$ 
Considering the importance of biotechnological processes and the search for thermostable enzymes of industrial interest produced by microorganisms, the present study aimed to produce two industrial enzymes, amylase and collagenase, obtained from Alicyclobacillus acidocaldarius and Alicyclobacillus sendaiensis, respectively, as well as to evaluate the immobilization of these microorganisms in order to improve enzyme production capacity. The use of agricultural and agroindustrial by-products as a substrate for enzyme production was a further focus of this research.

\section{EXPERIMENTAL SECTION}

\section{Materials}

Alicyclobacillus acidocaldarius CBMAI 0298 was obtained from the Brazilian Culture Collection of Microorganisms for Industry and Environment from São Paulo and Alicyclobacillus sendaiensis KCTC 3843 was obtained from the Korea Collection for Type Culture (KCTC). Soluble potato starch (S2004) and Azocoll were acquired from Sigma (St. Louis, MO, USA). The loofa sponge and wheat bran substrates and cassava flour were purchased in local stores (Maringá, Paraná, Brazil). The chemical composition of the wheat bran was evaluated and had the following composition $(\mathrm{g} / 100 \mathrm{~g})$ : humidity (10.50), proteins (15.01), lipids (4.94), ash (0.10), crude fiber (9.37), and carbohydrates (69.55). All the chemicals used in the study herein were analytical grade.

\section{Microorganisms and culture conditions}

The A. acidocaldarius was reactivated, and in accordance with the supplier's specifications, was maintained in the Bacillus acidoterrestris (BAT) culture medium, ${ }^{16,17} \mathrm{pH}$ 4.0. A. sendaiensis was reactivated and maintained in the potato dextrose broth medium, $\mathrm{pH}$ 4.8. The lyophilization process was performed to maintain the microorganisms in storage in the laboratory for use in subsequent experiments.

\section{Production of amylase by Alicyclobacillus acidocaldarius}

\section{Pre-inoculum preparation}

A total of $30 \mathrm{mg}$ of lyophilized cells were added to $100 \mathrm{~mL}$ of BAT medium in $250 \mathrm{~mL}$ Erlenmeyer flasks for reactivation. Incubation was performed for $24 \mathrm{~h}$ at $60{ }^{\circ} \mathrm{C}$ and $150 \mathrm{rpm}$. The cells were then centrifuged at $9000 \mathrm{rpm}$ for $10 \mathrm{~min}$ at $4{ }^{\circ} \mathrm{C}$, washed with $0.9 \%$ saline solution $(\mathrm{w} / \mathrm{v})$, and transferred to the enzyme production medium.

\section{Obtaining the enzyme extract of amylase}

The reactivated lyophilized cells were transferred to Erlenmeyer flasks containing $100 \mathrm{~mL}$ of BAT medium and $1 \%$ of starch (w/v) and other substrates for evaluation of the enzyme production. The following substrates were evaluated: soluble potato starch, cassava flour or wheat bran (commercial brand). Subsequently, the culture medium was incubated for $48 \mathrm{~h}$ at $60{ }^{\circ} \mathrm{C}$ and stirred at $150 \mathrm{rpm}$. Then, the medium was centrifuged at $9000 \mathrm{rpm}$ for $10 \mathrm{~min}$ at $4{ }^{\circ} \mathrm{C}$ and the cellfree supernatant (enzyme extract) was used for enzyme activity assays.

\section{Determination of amylase enzymatic activity}

Enzymatic activity was evaluated by determining the reducing sugars through the hydrolysis of the soluble potato starch. The reaction was performed by adding $250 \mu \mathrm{L}$ of substrate ( $1 \%$ soluble potato starch (w/v) in Mcllvaine buffer $\mathrm{pH}$ 3.0) and $250 \mu \mathrm{L}$ of enzyme extract, then incubating at $75^{\circ} \mathrm{C}$ for $30 \mathrm{~min}$, with the removal of one test tube every $5 \mathrm{~min}$. The quantity of reducing sugars was determined by the DNS ${ }^{18}$ method. A unit of enzyme activity was defined as the amount of enzyme which produced $1 \mu \mathrm{mol}$ of reducing sugar (glucose) per min, per ml of enzyme solution.

\section{Enzymatic characterization of amylase}

For the characterization of enzyme amylase, the enzymatic activity was evaluated according to the methodology described.

Determination of optimum $\mathrm{pH}$ and temperature of

A. acidocaldarius amylase

The influence of $\mathrm{pH}$ on the enzyme activity of the amylase was evaluated at $\mathrm{pH} 2.0$ to 8.0 in McIlvaine buffer and at a temperature of $75^{\circ} \mathrm{C}$. The effect of temperature was evaluated in the 50 to $85{ }^{\circ} \mathrm{C}$ range and at $\mathrm{pH} 3.0$.

\section{Stability of Alicyclobacillus acidocaldarius amylase in relation to $p H$}

Stability depending on $\mathrm{pH}$ was evaluated in the 2.0 to 5.0 range using McIlvaine buffer solution. For all the $\mathrm{pH}$ values selected, enzymatic extract was added to the buffer solution at a ratio of 1:2, without substrate, and incubated at $37{ }^{\circ} \mathrm{C}$ for $24 \mathrm{~h}$. At time slots of $0,3,6,9,12$ and $24 \mathrm{~h}$, a sample of $250 \mu \mathrm{L}$ was collected and added into tubes containing $250 \mu \mathrm{L}$ of $1 \%$ soluble potato starch substrate solution (w/v), and residual activity determined at $75^{\circ} \mathrm{C}$.

\section{Determination of thermic stability of amylase}

The thermic stability of $A$. acidocaldarius was assessed in the temperature range from 55 to $75{ }^{\circ} \mathrm{C}$, with $5{ }^{\circ} \mathrm{C}$ intervals. For each temperature measured, the enzyme extract was incubated without substrate for $280 \mathrm{~min}$. Every $40 \mathrm{~min}$, a sample of $250 \mu \mathrm{L}$ was collected, added to tubes containing $250 \mu \mathrm{L}$ of substrate solution $1 \%$ (w/v), and residual activity was evaluated at $75^{\circ} \mathrm{C}$. The $1 \%$ soluble potato starch substrate solution (w/v) was prepared in McIlvaine $\mathrm{pH} 3.0$ buffer.

Influence of substrate concentration on amylase enzyme activity

The influence of substrate concentration on the production of reducing sugars was evaluated. Assays were performed at $75{ }^{\circ} \mathrm{C}$ and $\mathrm{pH}$ 3.0. The soluble potato starch substrate was prepared at the following concentrations: $0.05 ; 0.1 ; 0.25 ; 0.5 ; 0.75 ; 1.0 ; 2.5$; $5.0 ; 7.5$ and $10.0 \%(\mathrm{w} / \mathrm{v})$. Based on the enzyme activity data a function of substrate concentration, the kinetic parameters apparent $\mathrm{Km}$ and Vmax were obtained. The values were determined using the Lineweaver-Burk graphic method. ${ }^{19}$

\section{Determination of amylase enzyme stability in storage}

Amylase stability in storage at $4{ }^{\circ} \mathrm{C}$ was determined over a period of 60 days using the best predetermined temperature and $\mathrm{pH}$ conditions. The residual activity was evaluated at 15-day intervals.

\section{Production of collagenase enzyme by Alicyclobacillus sendaiensis}

\section{Preparation of pre-inoculum}

Using $250 \mathrm{~mL}$ Erlenmeyer flasks, $30 \mathrm{mg}$ of lyophilized cells were added to $100 \mathrm{~mL}$ of potato dextrose broth for reactivation. Incubation was performed for $24 \mathrm{~h}$ at $55^{\circ} \mathrm{C}$ and $150 \mathrm{rpm}$. After this the cells were centrifuged at $9000 \mathrm{rpm}$ for $10 \mathrm{~min}$ at $4{ }^{\circ} \mathrm{C}$, washed in $0.9 \%$ saline solution (w/v), and transferred to the enzyme production medium.

Obtaining enzymatic extract from the collagenase enzyme

Following reactivation, the lyophilized cells were transferred to $250 \mathrm{~mL}$ Erlenmeyer flasks containing $100 \mathrm{~mL}$ of potato 
dextrose broth medium supplemented with $0.5 \% \mathrm{KH}_{2} \mathrm{PO}_{4}(\mathrm{w} / \mathrm{v})$. The incubation conditions were $48 \mathrm{~h}$ and $150 \mathrm{rpm}$ at $55^{\circ} \mathrm{C}$. After cultivation, the culture medium was centrifuged at $9000 \mathrm{rpm}$ for 10 min at $4{ }^{\circ} \mathrm{C}$ and the cell free supernatant was used for enzyme activity assays.

\section{Determination of enzyme activity}

Collagenolytic activity was evaluated in accordance with the method described by Chavira et al. ${ }^{20}$ with some modifications, using Azocoll as a chromogenic substrate. To prepare the substrate, the Azocoll was suspended in a $50 \mu \mathrm{mol}$ sodium acetate buffer with $\mathrm{pH} 4.0$, at a final concentration of $4 \mathrm{mg} \mathrm{mL}^{-1}$. Therefore, $500 \mu \mathrm{L}$ of Azocoll and $500 \mu \mathrm{L}$ of the enzyme were evaluated at $60{ }^{\circ} \mathrm{C}$ and $\mathrm{pH}$ 4.0 for $18 \mathrm{~h}$. The reaction was interrupted by adding $1 \mathrm{M}$ sodium phosphate at $\mathrm{pH} 7.0$, followed by cooling and centrifugation at 9000 $\mathrm{rpm}$ for $10 \mathrm{~min}$ at $4{ }^{\circ} \mathrm{C}$. The absorbance of the supernatant solution was measured at $540 \mathrm{~nm}$. One collagenolytic activity (U) unit was defined as the amount of enzyme which caused an increase in the optical density of 0.1 after $18 \mathrm{~h}$.

\section{Determination of protein concentration in the enzyme extracts of amylase and collagenase}

After the microorganisms cultivation in the culture medium to produce the amylase and collagenase enzymes, centrifugation was performed at $9000 \mathrm{rpm}$ for $10 \mathrm{~min}$ at $4{ }^{\circ} \mathrm{C}$ and the cell free supernatant was used for testing. Protein concentration was determined by the Bradford method ${ }^{21}$ at $595 \mathrm{~nm}$ using bovine serum albumin (SigmaAldrich, St. Louis, MO, USA) as standard.

\section{Production of enzymes by Alicyclobacillus acidocaldarius and Alicyclobacillus sendaiensis immobilized in loofa sponge, alginate-sponge and alginate}

To improve enzyme production, the microbial cells were immobilized by adsorption in loofa sponge matrix and by entrapment using sodium alginate and alginate-sponge.

The loofa sponge, obtained from the dry seedless fruit of Luffa cylindrica, was used as an immobilization support and was prepared in accordance with the methods described by Pazzetto et al. ${ }^{22}$ For the cell immobilization process by adsorption, three loofa sponge discs were added to the culture medium containing the reactivated microbial cells. The culture was maintained by incubation for 72 $\mathrm{h}$ and $150 \mathrm{rpm}$.

Immobilization by entrapment in an alginate-sponge matrix was performed according to Phisalaphong et al. ${ }^{23}$ with modifications. A $3 \%$ alginate solution $(\mathrm{m} / \mathrm{v})$ was prepared by dissolving the sodium alginate in a $0.9 \% \mathrm{NaCl}$ solution $(\mathrm{m} / \mathrm{v})$. The alginate solution was autoclaved and maintained at $4{ }^{\circ} \mathrm{C}$ overnight to facilitate deaeration. After 4 days of cultivation in a liquid medium, the cells were removed from the medium by centrifugation, resuspended in $5 \mathrm{~mL}$ of sterile $0.9 \% \mathrm{NaCl}$ solution $(\mathrm{w} / \mathrm{v})$ and added to $50 \mathrm{~mL}$ of $3 \%$ alginate solution $(\mathrm{w} / \mathrm{v})$ to form the alginate-cell mixture. Three sterile sponge discs were immersed in the alginate-cell mixture. The sponges were transferred to a $1.47 \% \mathrm{CaCl}_{2}$ solution (w/v) and maintained under light stirring for $15 \mathrm{~min}$. The disks were then washed three times in $0.9 \% \mathrm{NaCl}$ solution $(\mathrm{w} / \mathrm{v})$.

Immobilization in alginate without the presence of the sponge was also performed. In this case, the cells were resuspended in 5 $\mathrm{mL}$ of $0.9 \% \mathrm{NaCl}$ solution (w/v), added to $50 \mathrm{~mL}$ of $3 \%$ alginate solution (w/v) and the mixture was dripped into $100 \mathrm{~mL}$ of $1.47 \%$ $\mathrm{CaCl}_{2}$ solution (w/v), resulting in the formation of gel beads, which were washed in a $0.9 \% \mathrm{NaCl}$ solution $(\mathrm{w} / \mathrm{v})$.
After these procedures, the matrices with the immobilized cells were transferred to the enzyme production medium and incubated for $48 \mathrm{~h}$. Production was also evaluated for the free biomass subjected to the same treatments.

\section{Use of ultrafiltration membrane system for concentration of enzyme extract}

The free and immobilized biomass of A. acidocaldarius and A. sendaiensis were subjected to the ultrafiltration membrane system for concentration and semi-purification of the enzyme extract. After cultivation in the production medium, the enzyme extract was obtained by centrifugation at $9000 \mathrm{rpm}$ for $10 \mathrm{~min}$ at $4{ }^{\circ} \mathrm{C}$ and subjected to the Millipore ${ }^{\circledR}$ ultrafiltration membrane system with a nominal molecular weight limit (NMWL) of $30 \mathrm{kDa}$ and a diameter of $44.5 \mathrm{~mm}$, using an Amicon ${ }^{\circledR}$ device coupled to an agitating pump. The extract was concentrated twice (v:v) and the enzyme activity was evaluated. The results were compared with the assays without the use of ultrafiltration.

The enzyme activity yield (Y\%) after the ultrafiltration process was determined by the ratio between the final enzyme activity of the retentate (after ultrafiltration) and the initial enzyme activity (before ultrafiltration) (Eq.1).

$$
Y(\%)=\frac{\text { Retentate activity } \times \text { Final volume }}{\text { Initial activity } \times \text { Initial volume }} \times 100
$$

\section{Statistical analysis}

All the assays were performed in triplicate for each treatment. The results were subjected to variance analysis (ANOVA) and the Tukey test at a $5 \%$ significance level.

\section{RESULTS AND DISCUSSION}

\section{Production of amylase by Alicyclobacillus acidocaldarius CBMAI 0298 using different substrates}

Different substrates in the production of the amylase enzyme by A. acidocaldarius, such as soluble potato starch, cassava flour and wheat bran, were evaluated. The results of the enzymatic activity varied according to the substrate used, as shown in Table 1. After the microorganism cultivation in wheat bran, the enzyme activity was $0.45 \mathrm{U} \mathrm{mL}^{-1}$. This value was seven times higher than the activity following cultivation of the microorganism in soluble potato starch (0.06 $\left.\mathrm{U} \mathrm{mL}^{-1}\right)$, and cassava flour $\left(0.19 \mathrm{U} \mathrm{mL}^{-1}\right)$. The nutritional composition of wheat bran and the type of starch present may be responsible for this increased enzyme activity. Similarly, Rajoka et al., ${ }^{24}$ concluded that the nutritional composition of wheat bran contains appropriate quantities of carbohydrates, proteins, fats, fiber and ashes $(\mathrm{Ca}, \mathrm{Mg}, \mathrm{P}, \mathrm{K}, \mathrm{S})$, favored the microbial growth and enzymes production. Based on this result, wheat bran was selected for the production of the enzyme and to perform the subsequent

Table 1. Influence of different substrates on the production of amylase by Alicyclobacillus acidocaldarius

\begin{tabular}{lccc}
\hline Substrate & $\begin{array}{c}\text { Total activity } \\
\left(\mathrm{U} \mathrm{mL}^{-1}\right)\end{array}$ & $\begin{array}{c}\text { Protein } \\
\left(\mathrm{mg} \mathrm{mL}^{-1}\right)\end{array}$ & $\begin{array}{c}\text { Specific activity } \\
\left(\mathrm{U} \mathrm{mg}^{-1}\right)\end{array}$ \\
\hline Soluble potato starch & 0.06 & 0.054 & 1.11 \\
Cassava flour & 0.19 & 0.070 & 2.71 \\
Wheat bran & 0.45 & 0.124 & 3.63 \\
\hline
\end{tabular}


testing of the characterization of the enzyme extract. Kumar et al. ${ }^{25}$ described amylase activity for A. acidocaldarius MTCC 8766 of $0.78 \mathrm{U} \mathrm{mL}^{-1}$ using a substrate of soluble potato starch, while Bai et $a l,{ }^{26}$ obtained activity of $1.23 \mathrm{U} \mathrm{mL}^{-1}$ with a culture of Alicyclobacillus sp. in soluble potato starch.

Agroindustrial by-products have been evaluated as substrates for the production of amylase in order to reduce production costs through fermentation in solid state and submerged fermentation. Abd-Elhalem et al. ${ }^{27}$ used industrial waste in the production of the amylase enzyme by Bacillus amyloliquefaciens in submerged fermentation, and the residue from potato processing exhibited higher activity $\left(80.1 \mathrm{U} \mathrm{mL}^{-1}\right)$ than soluble starch $\left(72.3 \mathrm{U} \mathrm{mL}^{-1}\right)$. Amylase production from Bacillus cereus MTCC 1305 by solid state fermentation using wheat bran resulted in a greater production of this enzyme ( $\left.94 \mathrm{U} \mathrm{g}^{-1}\right)$ than by production with rice flakes $\left(34 \mathrm{U} \mathrm{g} \mathrm{g}^{-1}\right){ }^{28}$ The production of the amylase enzyme using these substrates for $A$. acidocaldarius was not found in the existing literature.

\section{Kinetic parameters of amylase produced by Alicyclobacillus acidocaldarius}

Determination of optimum $\mathrm{pH}$ and temperature of amylase

The effect of $\mathrm{pH}$ on amylase enzyme activity was evaluated in the range from 2.0 to 8.0 , and displayed optimum activity at $\mathrm{pH} 3.0$. The enzyme displayed more than $93 \%$ residual activity at $\mathrm{pH} 2.0$ to 5.0 , however its activity declined rapidly after $\mathrm{pH} 5.0$, and was almost zero in the range 6.0 to 8.0 .

The optimum $\mathrm{pH}$ of amylase enzymes varies according to the genus and species of the producing organisms, and literature describes a wide $\mathrm{pH}$ range (5.0 to 11.0 ) for these enzymes. ${ }^{29}$ With respect to species of Alicyclobacillus, the optimum $\mathrm{pH}$ range obtained in the present study was in accordance with the range reported in literature. The amylase enzyme produced by A. acidocaldarius ATCC 27009 had an optimum $\mathrm{pH}$ of 3.0, in a study by Matzke et al..$^{5}$ In studies by Kumar et al., ${ }^{25}$ of the production of amylase produced by $A$. acidocaldarius MTCC 8766, the optimum $\mathrm{pH}$ was 6.0. An acidic $\alpha$-amylase produced by Alicyclobacillus sp. A4 was also described, and exhibited an optimum $\mathrm{pH}$ of $4.2 .^{26}$

In terms of the effect of temperature, the maximum enzymatic activity was achieved at $75^{\circ} \mathrm{C}(100 \%$ of relative activity). In the range from 65 to $80^{\circ} \mathrm{C}$ the relative activity was greater than $60 \%$. According to literature, the amylase enzymes produced by microorganisms have optimum temperature ranges that vary from 45 to $115^{\circ} \mathrm{C} .{ }^{6,30}$ The results found in the present study were similar to those from studies by Bai et al., ${ }^{26}$ and Matzke et al., ${ }^{5}$ in the production of amylase by A. acidocaldarius.

The temperature effect on enzymatic activity was analyzed by the energy activation calculation, using the equation of Arrhenius to plot the activity $\left(\mathrm{A}_{\mathrm{e}}\right.$ expressed in $\mu \mathrm{mol}$ of glucose $\min \times \mathrm{mL}^{-1}$ ) against temperature inversion $\left(1 / \mathrm{T}\right.$ expressed in $\left.\mathrm{K}^{-1}\right)$. The values were adjusted by the equation $\mathrm{A}_{\mathrm{e}}=\mathrm{Q}_{\mathrm{e}}^{-(\mathrm{E} / \mathrm{RT})}\left(\mathrm{r}=0.9794\right.$ for $\left.\mathrm{T} \leq 75^{\circ} \mathrm{C}\right)$ and the energy activation value $\left(\mathrm{E}_{\mathrm{a}}\right)$ was $11.68 \mathrm{Kcal} \mathrm{mol}^{-1}$ (Figure 1). In other studies, the energy activation values reported were $7.52 \mathrm{Kcal} \mathrm{mol}^{-1}$ for amylase produced by Bacillus circulans ${ }^{31}$ and $41.13 \mathrm{kcal} \mathrm{mol}^{-1}$ for commercial amylase produced by Bacillus amyloliquefaciens. ${ }^{32}$ Therefore, the energy activation value depends on the producing microorganism.

\section{Effect of temperature and $\mathrm{pH}$ on stability of amylase}

The values selected for the study of the stability of amylase in relation to $\mathrm{pH}$ and temperature were evaluated based on the results obtained for the effect of $\mathrm{pH}$ and temperature on enzymatic activity. The enzymatic extract displayed thermic stability at temperatures

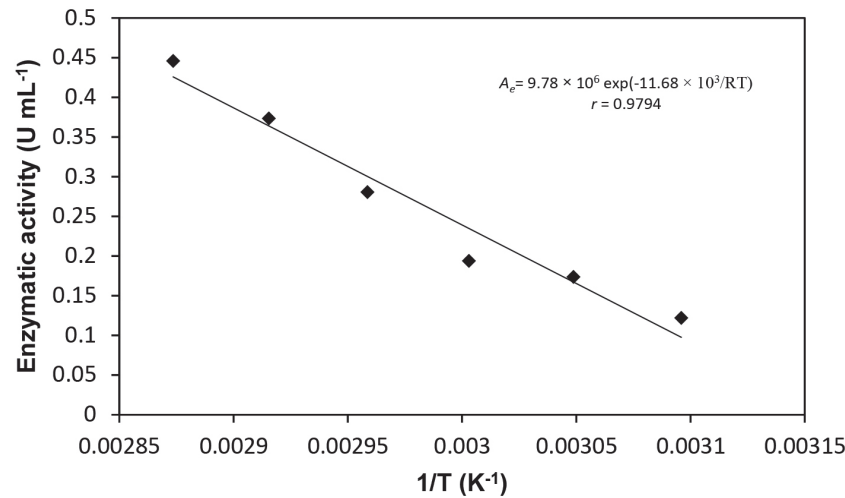

Figure 1. Arrhenius plot of the enzymatic activity as a function of the inverse of the absolute temperature for the amylase produced by Alicyclobacillus acidocaldarius CBMAI 0298

between 55 and $60{ }^{\circ} \mathrm{C}$, with $91 \%$ and $72 \%$ of residual activity, respectively, after $280 \mathrm{~min}$ of incubation (Figure $2 \mathrm{a}$ ). At temperatures of 65,70 and $75{ }^{\circ} \mathrm{C}$ there was a significant loss of residual activity after 20 min of incubation. When compared with other studies of the production of thermostable purified enzymes from Alicyclobacillus, this temperature range was also observed. ${ }^{25,33}$

In terms of stability and $\mathrm{pH}$, the enzyme extract displayed stability at all the $\mathrm{pH}$ values studied (Figure $2 \mathrm{~b}$ ). The enzyme displayed $72 \%$ of residual activity with $\mathrm{pH} 2.0$, and $80 \%$ of activity with $\mathrm{pH}$ values of 3.0 to 5.0 after $24 \mathrm{~h}$ of incubation. These results were similar to those of studies by Kumar e et al., ${ }^{25}$ for amylase enzymes produced by Alicyclobacillus acidocaldarius.
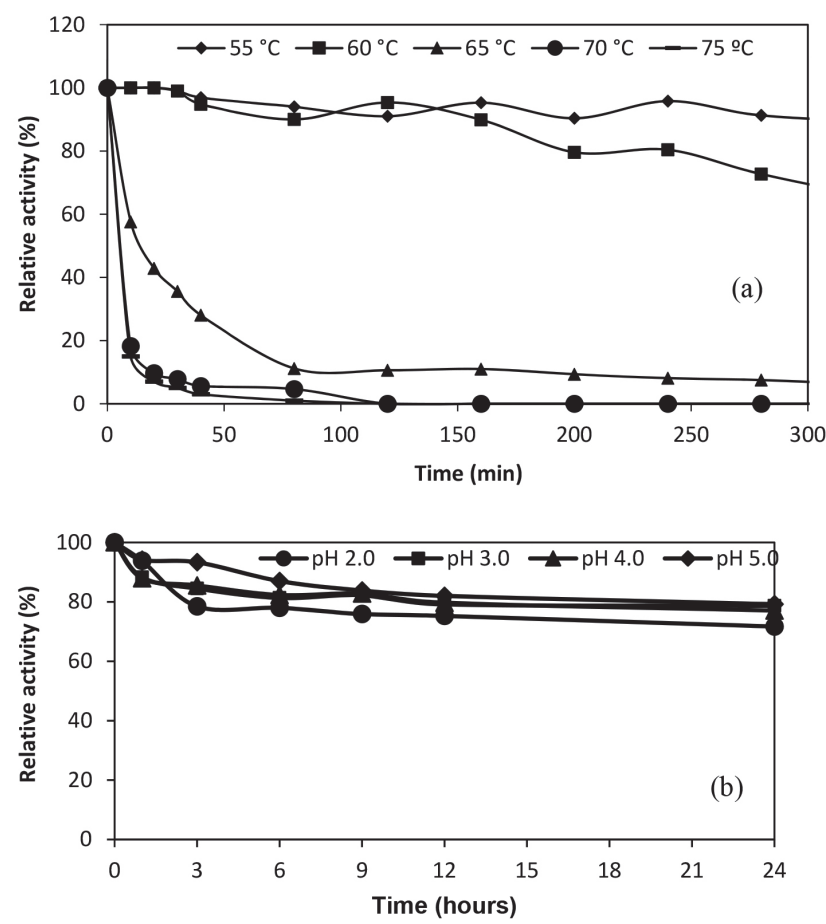

Figure 2. Effect of temperature (a) and $\mathrm{pH}(\mathrm{b})$ on stability of amylase. The activity of the enzyme was $100 \%$ at $\mathrm{pH} 3.0$ and a temperature of $75^{\circ} \mathrm{C}$. The activity of the non-heated enzyme was defined as 100\%

\section{Influence of substrate concentration on enzyme activity and} determination of kinetic parameters

Figure $3 \mathrm{a}$ shows the data of the reaction rate based on substrate concentration. Enzyme activity increased with an increased concentration of soluble potato starch in the range of 0.05 to $1 \%$ 
$(\mathrm{w} / \mathrm{v})$. Increasing the substrate concentration above $1 \%(\mathrm{w} / \mathrm{v})$ caused no significant increase in enzyme activity. Substrate inhibition was observed from the increase of $1 \%$ (w/v) of soluble starch with an apparent $\mathrm{Km}$ value of $3.2 \mathrm{mg} \mathrm{mL}^{-1}$.

With the results of the study on the influence of substrate concentration on the amylase enzyme activity, the kinetic parameters $K_{\text {mapparent }}$ and $V_{\max }$ were evaluated according to the Lineweaver-Burk model. The apparent $\mathrm{Km}$ and $\mathrm{Vmax}$ obtained were $3.2 \mathrm{mg} \mathrm{mL}^{-1}$ and $0.5 \mathrm{U} \mathrm{mL}^{-1}$, respectively (Figure $3 \mathrm{~b}$ ).

Literature reports $\mathrm{Km}$ values for amylase enzyme purified with starch substrate that vary from $0.16 \mathrm{mg} \mathrm{mL}^{-1}$ to $11.66 \mathrm{mg} \mathrm{mL}^{-1}$, depending on the microorganism used for the enzyme production. ${ }^{6}$ Considering that the parameter $K_{m}$ is inversely related to the enzyme affinity with the substrate, ${ }^{34}$ the values obtained in the present study indicate that the enzyme displayed good affinity with the substrate. $K_{m}$ values using purified enzymes close to the value obtained in the present study have been described, such as the value of $2.9 \mathrm{mg} \mathrm{mL}^{-1}$ obtained for amylase produced by $A$. acidocaldarius,${ }^{25}$ while other, greater values have also been reported, such as amylase from Bacillus circulans GRS, with a value of $11.66 \mathrm{mg} \mathrm{mL}^{-1} \cdot{ }^{31}$

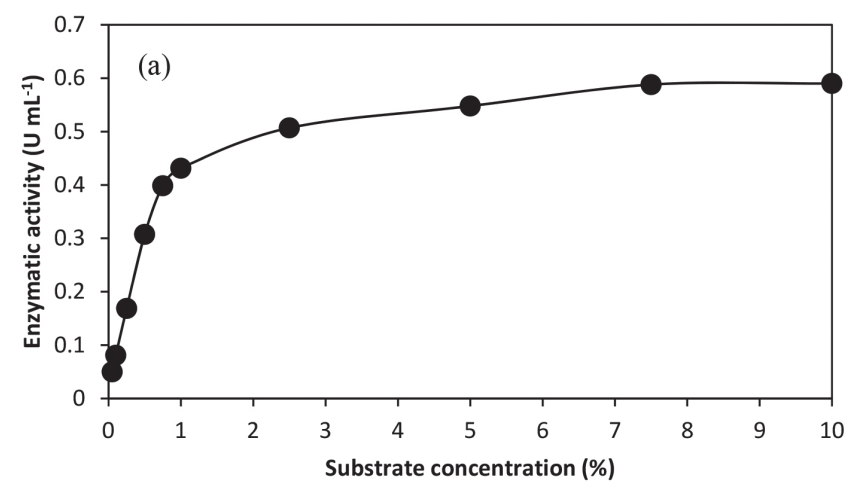

(b)

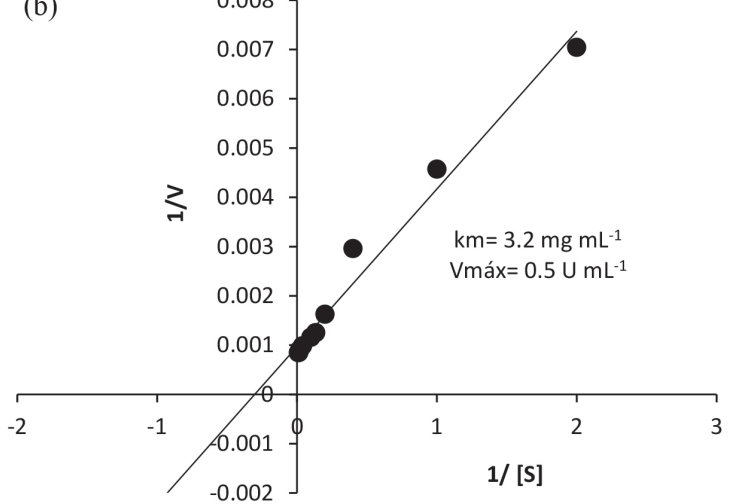

Figure 3. Effect of substrate concentration (soluble potato starch) on the enzymatic activity of amylase produced by Alicyclobacillus acidocaldarius (a). Graph of enzyme kinetic and apparent $K_{m}$ and $V_{\max }$ values according to Lineweaver-Burk (b)

\section{Evaluation of the stability of the enzyme extract in storage}

Enzymatic stability during storage is an important factor to enable commercialization since the production up to the final industrial use. There was no reduction in the activity of the enzyme extract after 60 days of storage, resulting in approximately $100 \%$ of the residual activity. Kumari et al. ${ }^{33}$ evaluated the storage stability of refrigerated acidophilic amylase enzyme produced by Bacillus cereus, and the results showed a $50 \%$ loss of residual activity after 30 days of storage.

\section{Production of collagenase by Alicyclobacillus sendaiensis} KCTC 3843

Potato dextrose broth supplemented with $0.5 \%$ (m/v) of $\mathrm{KH}_{2} \mathrm{PO}_{4}$ was used as substrate in the evaluation of the production of the collagenase enzyme by Alicyclobacillus sendaiensis KCTC 3843. Following the cultivation of the microorganism the enzymatic activity was $7.2 \mathrm{U} \mathrm{mL}^{-1}$ and the specific activity was $10 \mathrm{U} \mathrm{mg}^{-1}$. The result of the present study was close to that obtained by Lima et al. ${ }^{35}$ in the production of collagenase enzyme by Candida albicans, which had a value of $7.06 \mathrm{U} \mathrm{mL}^{-1}$. Nakayama et al. ${ }^{36}$ studied the production of collagenase enzyme by Bacillus NATP-1, previously described as A. sendaiensis ${ }^{4}$ and obtained enzymatic activity of $24 \mathrm{U} \mathrm{mL}^{-1}$ through the use of oxygen and $\mathrm{pH}$ control during enzyme production in a potato dextrose broth medium. These same authors also evaluated enzyme production in the presence of collagen and gelatin to $1.5 \%(\mathrm{w} / \mathrm{v})$, and found that this factor did not induce collagenase production.

Although the collagenase from A. sendaiensis obtained in the present study displayed a lower enzyme activity than previously published results, characterization of this enzyme was not performed. It is worth noting that collagenase enzymes are usually produced by mesophilic microorganisms, which exhibit optimum conditions for the hydrolysis of collagen in a neutral $\mathrm{pH}$ range (6-8) and at medium temperatures $\left(20-40^{\circ} \mathrm{C}\right)$. As an example of these microorganisms, literature describes production by Clostridium histolyticum, Bacillus licheniformis F11.4, and Bacillus pumilus. ${ }^{37,38}$ Therefore, despite the enzyme produced by $A$. sendaiensis having exhibited low collagenolytic activity, the reaction took place in thermophilic and acidic reaction conditions, relevant characteristics for the suppression of microbial contamination of the medium during the reaction processes. $^{4}$

Amylase and collagenase production by free and immobilized cells in different matrices of Alicyclobacillus acidocaldarius and Alicyclobacillus sendaiensis

The A. acidocaldarius immobilization in loofa sponge contributed to an increase in the enzymatic activity of amylase, differing significantly from the enzyme activity obtained with the free biomass, or $0.56 \mathrm{U} \mathrm{mL}^{-1}$ and $0.45 \mathrm{U} \mathrm{mL}^{-1}$, respectively (Figure $4 \mathrm{a}$ ). It can be suggested that the efficient immobilization of A. acidocaldarius in loofa sponge was due to the biofilm production of these organisms occurring in favorable fermentation medium conditions, favoring adhesion in the sponge ${ }^{39}$ or due to stress conditions induced by immobilization. ${ }^{40}$ The advantage of using loofa sponge in immobilization systems for industrial use is their low cost and also the ability to reuse the matrix in operating cycles.

Amylase activity from the enzymatic extract produced by $A$. acidocaldarius immobilized in alginate-sponge and alginate was $0.37 \mathrm{U} \mathrm{mL}^{-1}$ and $0.20 \mathrm{U} \mathrm{mL}^{-1}$, respectively. These values were lower than those obtained with free cells and also with the immobilized loofa sponge. The formation of alginate for the retention of cells may have resulted in the reduced transfer of amylase to the fermentation medium ${ }^{13}$ and thereby influenced catalytic activity.

For the collagenase enzyme produced by A. sendaiensis, it was found that the best enzyme activity results were obtained with the use of the free biomass $\left(7.23 \mathrm{U} \mathrm{mL}^{-1}\right)$ when compared with the immobilization matrices (Figure 4b). Among the immobilization systems, immobilizing the microorganism in loofa sponge (3.17 $\left.\mathrm{U} \mathrm{mL}^{-1}\right)$ resulted in the greatest enzymatic activity.

While existing literature does not include reports on the use of immobilization in loofa sponge for the production of enzymes from microorganisms of the Alicyclobacillus genus, there are studies 
on the production of enzymes and polysaccharides using a variety of immobilized microorganisms. Pazzetto et al., ${ }^{22}$ evaluated the production of $\beta-\mathrm{CD}$ by strain 37 immobilized Bacillus firmus in similar matrices to the present study, and immobilization in loofa sponge and alginate-sponge provided better results than with free cells.

Kar et al., ${ }^{41}$ studied the effect of different matrices in the Streptomyces erumpens immobilization for the amylase production, and verified that the loofa sponge presented excellent support due to the high value of aggregate biomass, being 21 and 51\% more efficient than agar-agar and polyacrylamide also used, respectively.
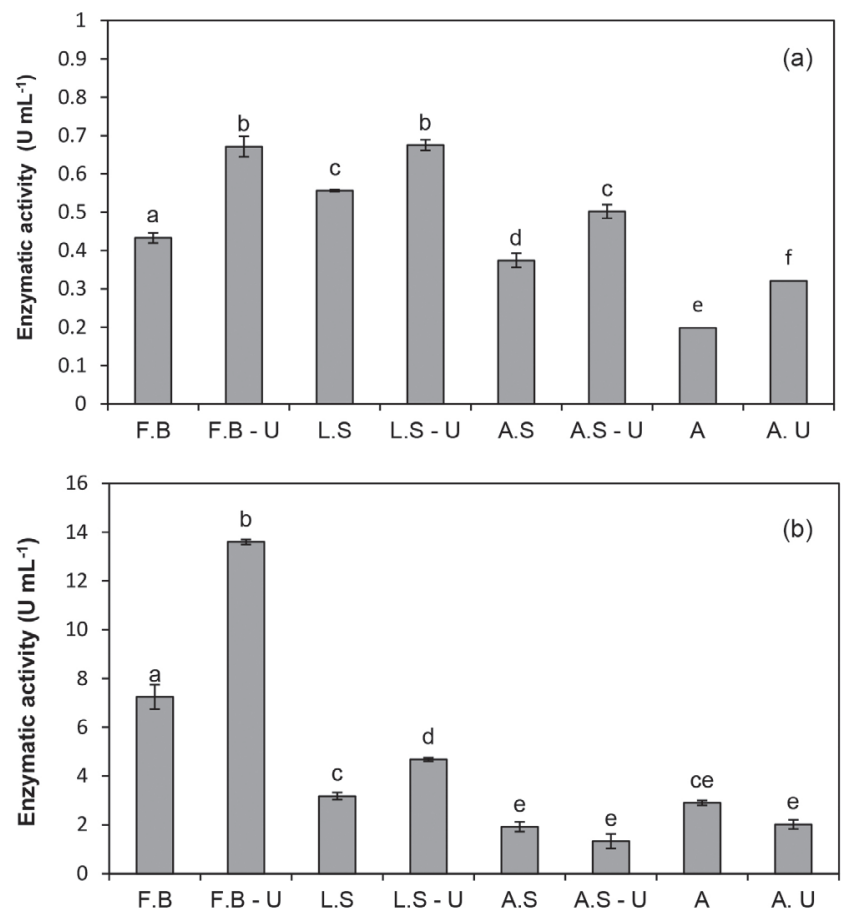

Figure 4. Enzymatic activity of amylase (a) and collagenase (b) immobilized in loofa sponge, alginate-sponge, alginate and free biomass with and without ultrafiltration system. F.B: Free Biomass, L.S: Loofa Sponge, A.S.: Alginate-sponge, A: Alginate. U: Ultrafiltration. Means followed by the same letters did not significantly differ according to Tukey's test $(P<0,05)$

\section{Use of ultrafiltration membrane system for concentration of enzyme extracts}

While the use of enzymes such as amylases does not generally require a purified form for commercial applications, their application in the pharmaceutical and medical industries requires high purity. ${ }^{6}$ Thus, in the present study, after obtaining the enzyme extracts from the microorganisms, a concentration process through ultrafiltration membrane was performed in order to carry out the partial purification and concentration of the enzyme extract.

After the use of the ultrafiltration system, the enzyme activity for both enzymes was evaluated, and an increase in values was found (Figure $4 \mathrm{a}$ and $4 \mathrm{~b}$ ). For the semi-purified amylase extract, the highest activity was obtained from the use of the enzyme concentrate cultivated by free cells and from the microorganism immobilized in loofa sponge, which was $55 \%$ higher than the free biomass without ultrafiltration. For the semi-purified extract of collagenase, the enzyme activity obtained with the free cells exhibited better results, and was $53 \%$ greater than without ultrafiltration extract. Gottschalk et al.,${ }^{14}$ studied the enzyme produced by Streptomyces viridosporus $\mathrm{T} 7 \mathrm{~A}$, and reported that the use of ultrafiltration was considered an effective option to concentrate the enzyme activity of the crude extract.

To verify the yield of enzymatic activity after using the ultrafiltration system the equation 1 which was described in the methodology used, and average values obtained are shown in Table 2. For the amylase enzyme, the highest yield was obtained with cells immobilized in alginate, however this was not a significant result when compared to the results obtained with free cells. The yield values for amylase were close to those obtained in a study by Bai et al. ${ }^{26}$

For collagenase enzyme, the highest yield was obtained with the use of free cells, corroborating the enzymatic activity presented above. The immobilization in alginate and alginate-sponge systems did not exhibit satisfactory results, possibly due to problems with the distribution of the enzyme in the culture medium, considering that these are immobilization by imprisonment systems. Thus, the ultrafiltration membrane has been proven to be a viable concentration method, enabling partial purification as well as being simple and quick to perform.

Table 2. Enzyme activity yield after concentration by ultrafiltration membrane for amylase and collagenase produced by Alicyclobacillus acidocaldarius and Alicyclobacillus sendaiensis, respectively

\begin{tabular}{lcc}
\hline \multirow{2}{*}{ Immobilizing support } & \multicolumn{2}{c}{ Yield (\%) } \\
\cline { 2 - 3 } Free Biomass & Amylase & Collagenase \\
Loofa sponge & 77.0 & 94.0 \\
Alginate-sponge & 60.7 & 74.0 \\
Alginate & 67.0 & 35.0 \\
\hline
\end{tabular}

\section{CONCLUSION}

The present study found that it was possible to produce amylase and collagenase by A. acidocaldarius and A. sendaiensis respectively, with amylase exhibiting thermostable characteristics. Industrial byproduct was used for amylase production, including wheat bran substrate, which was the best substrate for this enzyme, and was thus an economically viable option for industry. The enzyme extract from A. acidocaldarius selected for characterization exhibited favorable properties such as stability at high temperatures and low $\mathrm{pH}$ values, as well as stability in refrigerated storage. The use of immobilization systems provided an increase in the amylase enzymatic activity, especially when loofa sponge was used as an immobilization matrix. For collagenase, the immobilization results did not differ significantly among themselves in comparison with the use of free cells. The use of the ultrafiltration system was favorable for both enzyme extracts, and it is a possible candidate for use in industrial enzyme preparations in the starch and collagen hydrolysis.

\section{ACKNOWLEDGEMENTS}

The authors would like to thank the Coordenação de Aperfeiçoamento de Pessoal de Nível Superior (CAPES), Conselho Nacional de Desenvolvimento Científico e Tecnológico (CNPQ), and Fundação Araucária (FA) for financially supporting this study.

\section{REFERENCES}

1. Goto, K.; Mochida, K.; Asahara, M.; Suzuki, M.; Kasai, H.; Yokota, A.; Int. J. Syst. Evol. Microbiol. 2003, 53, 1537.

2. Yuan, T.; Yang, P.; Wang, Y.; Meng, K.; Luo, H.; Zhang, W.; Wu, N.; Fan, Y.; Yao, B.; Biotechnol. Lett. 2008, 30, 348. 
3. Xie, Z.; Xu, B.; Junmei, D.; Lingyun, L.; Zhang, X.; Li, J.; Huang, Z.; Biotechnol. Lett. 2013, 35, 1283.

4. Tsuruoka, N.; Nakayama, T.; Ashida, M.; Hemmi, H.; Nakao, M.; Minakata, H.; Appl. Environ. Microbiol. 2003, 69, 162.

5. Matzke, J.; Herrmann, A.; Schneider, E.; Bakker, E. P.; FEMS Microbiol. Lett. 2000, 183, 55.

6. Sharma, A.; Satyanarayana, T.; Process Biochem. 2013, 48, 201.

7. Goyal, N.; Gupta, J. K.; Soni, S. K; Enzyme Microb. Technol. 2005, 37, 723.

8. Gupta, R.; Gigras, P.; Mohapatra, H.; Goswami, V. K.; Chauhan, B; Process Biochem. 2003, 38, 1599.

9. Ravanti, L.; Kahari, V. M.; Int. J. Mol. Med. 2000, 6, 391.

10. Jamuna, R.; Ramakrishna, S. V.; Enzyme Microb. Technol. 1992, 14, 36.

11. Konsoula, Z.; Liakopoulou-Kiriakides, M; Enzyme Microb. Technol. 2006, 39, 690.

12. Iqbal, M.; Saeed, A.; Edyvean, R. G. J.; O'Sullivan, B.; Styring, P.; Biotechnol. Lett. 2005, 27, 1319.

13. Delani, T. C. O.; Pazzeto, R.; Mangolim, C. S.; Fenelon, V. C.; Moriwaki, C.; Matioli, G. Int. J. Mol. Sci. 2012, 13, 13294.

14. Gottschalk, L. M. F.; Bom, E. P. S.; Nobrega, R.; Appl. Biochem. Biotechnol. 2008, 147, 23.

15. Krstic, D. M.; Antov, M. G.; Pericin, D. M.; Höflinger, W.; Tekic, M. N.; Biochem. Eng. J. 2007, 33, 10.

16. Darland, G.; Brock, T. D; J. Gen. Microbiol. 1971, 67, 9.

17. Deinhard, G.; Blanz, P.; Poralla, K.; Altan, E.; Syst. Appl. Microbiol. 1987, 10, 47.

18. Miller, G. L.; Anal. Chem. 1959, 3, 426.

19. Lineweaver, H.; Burk, D.; J. Am. Chem. Soc. 1934, 56, 658.

20. Chavira Jr., R.; Burnett, T. J.; Hageman, J. H.; Anal. Biochem. 1984, 136, 446.

21. Bradford, M. M.; Anal. Biochem. 1976, 72, 248.

22. Pazzetto, R.; Delani, T. C. O.; Fenelon, V. C.; Matioli, G.; Process Biochem. 2011, 46, 46.

23. Phisalaphong, M.; Budiraharjo, R.; Bangrak, P.; Mongkolkajit, J.; Limtong, S.; J. Biosci. Bioeng. 2007, 104, 214.
24. Rajoka, M. I.; Akhtar, M.W.; Hanif, A.; Khalid, A. L.; World J. Microbiol. Biotechnol. 2006, 22, 991.

25. Kumar, G. S.; Chandra, M. S.; Mallaiah, K. V.; Sreenivasulu, P.; Choi, Y.-L.; Biotechnol. Bioprocess Eng. 2010, 15, 435.

26. Bai, Y.; Huang, H.; Meng, K.; Shi, P.; Yang, P.; Luo, H.; Luo, C.; Feng, Y.; Zhang, W.; Yao, B; Food Chem. 2012, 131, 1473.

27. Abd-Elhalem, B. T.; El-Sawy, M.; Gamal, R. F.; Abou-Taleb K. A.; Ann. Agric. Sci. 2015, 60, 193.

28. Anto, H.; Trivedi, U.; Patel, K.; Food Technol. Biotechnol. 2006, 44, 241.

29. Pandey, A.; Nigam, P.; Soccol, C. R.; Soccol, V. T.; Singh, D.; Mohan, R.; Biotechnol. Appl. Biochem. 2000, 31, 135.

30. Gomes, E.; Guez, M. A. U.; Martin, N.; Silva, R.; Quim. Nova. 2007, 30, 136.

31. Dey, G.; Palit, S.; Banerjee, R.; Maiti, B. R.; J. Ind. Microbiol. Biotechnol. 2002, 28, 193

32. Rodriguez, V. B.; Alameda, E. J.; Gallegos, J. F. M.; Requena, A. R.; Lopez, A. I. G.; Biochem. Eng. J. 2006, 27, 299.

33. Kumari, N.; Jain, V.; Malhotra, S.; Afr. J. Microbiol. Res. 2013, 48, 5440.

34. Matioli, G.; Moraes, F. F.; Zanin, G. M.; Appl. Biochem. Biotechnol. 2000, 61, 98 .

35. Lima, C.; Rodrigues, P.; Porto, T.; Viana, D.; Lima filho, J.; Porto, A.; Carneiro da Cunha, M.; Lima, C. A.; Biochem. Eng. J. 2009, 43, 315.

36. Nakayama, T.; Tsuruoka, N.; Akai, M.; Nishino, T.; J. Biosci. Bioeng. 2000, 89,612 .

37. Daboor, S. M.; Budge, S. M.; Ghaly, A. E.; Brooks, Su-Ling.; Dave, D.; Am. J. Biochem. Biotechnol. 2010, 6, 239.

38. Wu, Q.; Li, C.; Li, C.; Chen, H.; Shuliang, L.; Appl. Biochem. Biotechnol. 2010, 160, 129.

39. Ciuffreda, E.; Bevilacqua, A.; Sinigaglia, M.; Corbo, M. R.; Microorganisms 2015, 3, 625.

40. Gomez, J. M.; Cantero, D.; Webb, C.; Appl. Microbiol. Biotechnol. 2010, $54,335$.

41. Kar, S.; Swain, M. R.; Ray, R. C.; Appl. Biochem. Biotechnol. 2009, 152, 177. 